\title{
IMPLEMENTASI E-FILLING DAN KUALITAS PELAYANAN PADA KEPATUHAN WAJIB PAJAK ORANG PRIBADI DI KANTOR PELAYANAN PAJAK (KPP) BANDAR LAMPUNG
}

\author{
Eha Nugraha ${ }^{(1)^{*}}$, Aderina Kusuma Harahap ${ }^{(2)}$, Hesti Widi Astuti ${ }^{(3)}$ \\ ${ }^{1}$ Akuntansi,STIE Al Madani, ${ }^{2}$ Manajemen, Institut Informatika Dan Bisnis Darmaya, Manajemen, \\ ${ }^{3}$ Universitas Sang Bumi Ruwa Jurai
}

Eha.nugraha@almadani.ac.id,aderinaharahap@darmajaya.ac.id,hesti172112@gmail.com,

\begin{abstract}
Abstrak. Penelitian ini bertujuan untuk mengetahui Implementasi E-Filling dan kualitas pelayanan pada kepatuahan wajib pajak orang pribadi di kantor pelayanan pajak (KPP) Bandar Lampung. Jenis penelitian ini menggunakan metode kualitatif digunakan interprestasi adari data kuantitatif dengan teknik analisis jalur. Teknik pengumpulan data dengan cara melakukan survey yaitu pengambilan data secara langsung maupun tidak langsung Hasil dari penelitian ini adalah sebagai berikut analisis pengaruh X1 terhadap X2 dari analisis di atas diperoleh nilai signifikansi X1 sebesar $0,000<0,05$, sehingga dapat disimpulkan bahwa variabel implementasi e-filling (X1) berpengaruh terhadap kualitas pelayanan (X2), analisis pengaruh X1 terhadap Y2 dari analisis di atas diperoleh nilai signifikansi X1 sebesar $0,000<0,05$, analisis pengaruh X2 terhadap Y2 dari analisis di atas diperoleh nilai signifikansi sebesar 0,122>0,05 analisis pengaruh X1 terhadap Y2 dari analisis di atas diperoleh nilai signifikansi sebesar $0,035<0,05$ sehingga dapat disimpulkan bahwa variabel implementasi e-filling (X1) berpengaruh terhadap kepatuhan wajib pajak orang pribadi (Y2), analisis pengaruh X1 terhadap Y2 dari analisis di atas diperoleh nilai signifikansi sebesar $0,000<0,05$ sehingga dapat disimpulkan bahwa variabel implementasi e-filling (X1) berpengaruh terhadap kepatuhan wajib pajak orang pribadi (Y2).
\end{abstract}

Kata Kunci: Implementasi e-filling, Kualitas Pelayanan, Sanksi Perpajakan, Kepatuhan Wajib Pajak Orang Pribadi.

\section{PENDAHULUAN}

Langkah pemerintah untuk meningkatkan penerimaan dari sektor perpajakan dimulai dengan melakukan reformasi perpajakan secara menyeluruh pada tahun 1983, dan sejak saat itulah, Indonesia menganut sistem self assesment. Penerapan self assesment system akan efektif apabila kondisi kepatuhan sukarela (voluntary compliance) pada masyarakat telah terbentuk.(Damayanti, 2004) Kenyataan yang ada di Indonesia menunjukkan tingkat kepatuhan masih rendah, hal ini bisa dilihat dari belum optimalnya penerimaan pajak yang tercermin dari tax gap dan tax ratio.

Data yang akurat mengenai berapa jumlah tax gap Indonesia belum tersedia. Namun dalam pidato pengukuhannya sebagai guru besar Fakultas Ekonomi Universitas Indonesia, Gunadi mengutip hasil laporan Badan Pemeriksa Keuangan dan Pembangunan (BPKP) tentang audit kinerja Direktorat Jenderal Pajak, bahwa Indonesia mengalami tax gap yang cukup signifikan

Tinggi rendahnya penerimaan pajak dapat dipengaruhi beberapa faktor, salah 
satunya adalah pelaporan Wajib Pajak dengan e-filling. E-filling adalah sebuah layanan pengiriman atau penyampaian Surat Pemberitahuan Pajak (SPT) secara elektronik, baik untuk Orang Pribadi (OP) maupun Badan ke Direktorat Jenderal Pajak (DJP) dengan menggunakan jaringan internet melalui ASP (Application Service Provider atau Penyedia Jasa Aplikasi) seperti Laporpajak.com, sehingga WP (wajib pajak) tidak perlu lagi melakukan pencetakan semua formulir laporan.

Saat ini e-filling telah umum digunakan dibeberapa negara di dunia. Indonesia sendiri mulai mengadopsi teknologi e-filing ini sekitar tahun 2003. Didunia terdapat beberapa metode penggunaan e-filling. Negara-negara yang mempunyai tidak begitu banyak wajib pajak umumnya mengadopsi teknologi e- filling dengan menggunakan server pemerintah, sedangkan negara-negara yang mempunyai wajib pajak "segambreng" seperti Indonesia, mereka menggunakan provider khusus untuk menyediakan layanan e- filing.

Salah satu faktor yang mempengaruhi penerimaan pajak selain e-filling adalah kepuasan Wajib Pajak, dalam hal pelayanan pajak adalah melalui Fiskus. Menurut jatmiko menjelaskan Pelayanan fiskus dapat diartikan sebagai cara petugas pajak dalam membantu mengurus atau menyiapkan segala keperluan yang dibutuhkan seseorang (dalam hal ini adalah WP). Para WP akan patuh apabila petugas pajak memberikan mutu pelayanan terbaik kepada WP (Ihsan, 2013).

Pelayanan dikatakan berkualitas apabila pelayanan yang cepat memberikan kepuasan kepada WP. Semakin puas WP terhadap pelayanan perpajakan, semakin luas pemahaman wajib pajak terhadap ketentuan dan perundang-undangan perpajakan, semakin tinggi tingkat kepatuhan perpajakannya (Astari, 2011). Menurut Parasuraman Ada lima aspek agar kualitas pelayanan memberikan kepuasan bagi pengguna jasa meliputi hal-hal sebagai berikut (1) Reliability (keandalan), (2) Assurance (jaminan), (3) Empaty (empati), (4) Responsieveness (ketanggapan), (5) Tangible (bukti langsung).

Untuk mencapai target pajak, perlu ditumbuhkan terus menerus kesadaran dan kepatuhan masyarakat wajib pajak untuk memenuhi kewajiban pajak sesuai dengan ketentuan yang berlaku. Mengingat kesadaran dan kepatuhan wajib pajak merupakan faktor penting bagi peningkatan penerimaan pajak, maka perlu secara intensif dikaji tentang faktor-faktor yang mempengaruhi kepatuhan wajib pajak, khususnya wajib pajak orang pribadi.

Sasaran dalam penelitian ini akan difokuskan pada wajib pajak orang pribadi yang melakukan kegiatan usaha dan pekerjaan bebas. Wajib pajak orang pribadi yang melakukan kegiatan usaha atau pekerjaan bebas adalah orang pribadi yang menyelenggarakan kegiatan usaha dan tidak terikat oleh suatu ikatan dengan pemberi kerja. Wajib pajak orang pribadi yang melakukan kegiatan usaha menjalankan usaha seperti usaha dagang, jasa, industri, dan lain-lain, sedangkan yang dimaksud dengan pekerjaan bebas yaitu pekerjaan yang dilakukan oleh orang pribadi yang mempunyai keahlian khusus sebagai usaha untuk memperoleh penghasilan dan tidak terikat oleh suatu ikatan dengan pemberi kerja. Contoh pekerjaan bebas yaitu praktek pribadi sebagai dokter, konsultan, pengacara, dan lain-lain.

Kesadaran wajib pajak atas fungsi perpajakan sebagai pembiayaan negara sangat diperlukan untuk meningkatkan kepatuhan wajib pajak (Jatmiko, 2006). Menurut Suardia (dikutip dari Muliari dan 
Setiawan, 2010), masyarakat harus sadar akan keberadaannya sebagai warga negara dan harus selalu menjunjung tinggi UndangUndang Dasar 1945 sebagai dasar hukum penyelenggaran negara. Pelayanan fiskus yang baik diharapkan mampu meningkatkan kepatuhan wajib pajak. Dalam penelitian Supadmi (2010) disebutkan bahwa untuk meningkatkan kepatuhan wajib pajak dalam memenuhi kewajiban perpajakannya, kualitas pelayanan pajak harus ditingkatkan oleh aparat pajak.

Kemauan Wajib Pajak dalam membayar kewajiban perpajakannya merupakan hal penting dalam rangka optimalisasi penerimaan pajak. Kemauan membayar pajak (willingness to pay tax) dapat diartikan sebagai suatu nilai yang rela dikontribusikan oleh seseorang (yang ditetapkan dengan peraturan) yang digunakan untuk membiayai pengeluaran umum negara dengan tidak mendapat jasa timbal (kontraprestasi) secara langsung(Tatiana, 2009)

Pelayanan yang berkualitas merupakan harapan yang didambakan oleh masyarakat karena Wajib Pajak menganggap bahwa hal itu merupakan "hak" yang harus diperoleh sebagai umpan balik atas pelaksanaan "kewajibannya" dalam membayar pajak. Penegakan hukum dibidang perpajakan adalah tindakan yang dilakukan oleh Fiskus untuk menjamin agar Wajib Pajak dan calon wajib pajak memenuhi ketentuan undang-undang perpajakan seperti menyampaikan SPT, pembukuan dan informasi lain yang relevan serta membayar pajak pada waktunya. Sarana penegakan akibat ketidak patuhan wajib pajak dapat meliputi sanksi atas kelalaian menyampaikan SPT, bunga yang dikenakan atas keterlambatan pembayaran dan dakwaan pidana dalam hal terjadi penyelundupan pajak.
Menurut Kamus Besar Bahasa Indonesia Penerapan adalah menerapkan, mempraktekkan ilmu dalam kehidupan sehari-hari (Kamus Bahasa Indonesia, 2008). Browne dan Wildavsky dalam Nurdin dan Usman, mengemukakan bahwa implementasi adalah perluasan aktivitas yang saling menyesuaikan (Browne, 2004).

Berdasarkan Keputusan Direktur Jenderal Pajak Nomor : KEP- 88/PJ./2004 tanggal 14 Mei 2004 jo KEP-05/PJ./2005 tanggal 12 Januari 2005 tentang Tata Cara Penyampaian Surat Pemberitahuan Secara Elektronik (e-filing) melalui Perusahaan Penyedia Jasa Aplikasi (ASP): E-filing atau e-SPT adalah Surat Pemberitahuan Masa atau Tahunan yang berbentuk formulir elektronik dalam media komputer, dimana penyampaiannya dilakukan secara elektronik dalam bentuk data digital yang ditransfer atau disampaikan ke Direktorat Jenderal Pajak melalui Perusahaan Penyedia Jasa Aplikasi atau Application Service Provider (ASP) yang telah ditunjuk oleh Direktur Jenderal Pajak dengan proses yang terintegrasi dan real time.

Definisi e- filling menurut Liberty Pandiangan (2007) menyebutkan, E-filing adalah layanan pengisian dan penyampaian Surat Pemberitahuan (SPT) Wajib Pajak secara elektronik kepada Direktorat Jenderal Pajak dengan memanfaatkan jaringan komunikasi internet. Sedangkan Menurut Sugiarto dan Wahyono (2005) mengatakan bahwa e-filling adalah Kearsipan atau filling adalah suatu bentuk pekerjaan tata usaha yang berupa penyusunan dokumendokumen secara sistematis sehingga bilamana diperlukan lagi, dokumendokumen itu dapat ditemukan kembali secara cepat, sedangkan menurut Siti Kurnia (2010) mendefinisikan e-filling sebagai berikut : Merupakan cara penyampaian SPT melalui sistem online dan Real Time. Wajib Pajak dapat menyampaikan SPT melalui perusahaan penyedia jasa aplikasi 
(aplication service provider) yang telah ditunjuk DJP sebagai perusahaan yang dapat menyalurkan penyampaian.

Menurut Sugiarto dan Wahyono (2005) mengatakan bahwa e-filling adalah: Kearsipan atau filling adalah suatu bentuk pekerjaan tata usaha yang berupa penyusunan dokumen-dokumen secara sistematis sehingga bilamana diperlukan lagi, dokumen-dokumen itu dapat ditemukan kembali secara cepat.

Menurut Hendi Haryadi (Haryadi, 2009)komponen dasar yang bisa dijadikan pegangan dalam memilih sistem kearsipan elektronik yaitu: 1) Ketersedian yang luas dan akses yang fleksibel: caranya dengan menyediakan beberapa cara untuk mengakses file. dengan level akses yang luas akan menghemat dana modal suatu jaringan karena pemanfaatannya yang optimal. Metode yang biasa digunakan untuk mengintergrasikan seluruh komputer dengan setiap pengguna (client based user interface) akan memungkinkan penscan-an pengindeksan, atau penemuan kembali suatu arsip. Manajemen arsip elektronis harus dapat memenuhi kebutuhan masing-masing pengguna dengan lokasi yang berbeda; 2) Keamanan yang komprehensif: sebuah organisasi yang menginplementasikan arsip elektronik dengan dokumen yang bervariasi hendaknya meningkatkan keamanan dengan melakukan kontrol akses yang komprehensif dan sederhana. Hal ini akan memungkinkan administrator sistem mengontrol folder dan dokumen apa yang bisa diakses, dilihat, di copy, bahkan di edit atau dihapus oleh seorang pengguna, sedangkan menurut (Lai, 2012) menyatakan bahwa e-filling dipengaruhi oleh beberapa faktor sebagai berikut: 1) usage intention (minat penggunaan); 2) attitude (sikap); 3) perceived ease of use (kemudahan penggunaan persepsi); 4) perceived usefulness (kegunaan persepsi); dan 5) compliance (kepatuhan)

Pelayanan adalah cara melayani (membantu mengurus atau menyiapkan segala keperluan yang dibutuhkan seseorang). Sementara itu fiskus adalah petugas pajak. Sehingga pelayanan fiskus dapat diartikan sebagai cara petugas pajak dalam membantu mengurus atau menyiapkan segala keperluan yang dibutuhkan seseorang (dalam hal ini adalah wajib pajak). Tingkat keberhasilan penerimaan pajak selain dipengaruhi oleh tax payer juga di pengaruhi oleh tax policy,tax law dan tax administratio Prastiantono, 2004. Tiga faktor terakhir ini melekat dan dikendalikan oleh fiskus itu sendiri, sedangkan faktor tax payer didominasi dari dalam diri wajib pajak itu sendiri.

$\begin{array}{ccc}\text { Petugas } & \text { pajak (Fiskus) dalam } \\ \text { melaksanakan } & \text { tugasnya melayani }\end{array}$ masyarakat atau wajib pajak sangat di pengaruhi oleh adanya tax policy,tax law dan tax administration. Loekman Sutrisno Kepatuhan wajib pajak dalam memenuhi kewajibanya membayar pajak tergantung pada bagaimana petugas pajak. Fiskus diharapkan memiliki kompetensi dalam arti memiliki keahlian (skill), pengetahuan (knowledge), dan pengalaman (experience) dalam hal kebijakan perpajakan, administrasi pajak dan perundang- undangan perpajakan.Selain itu fiskus harus memiliki motivasi yang tinggi sebagai pelayanpublik.

Kegiatan yang dilakukan otoritas pajak dengan menyapa masyarakat agar menyampaikan SPT tepat waktu termasuk penyuluhan secara kontinyu melalui berbagai media.Dengan penyuluhan secara terus menerus kepada masyarakat agar mengetahui, mengakui, menghargai, dan menaati ketentuan pajak diharapkan tujuan pajak dapat berhasil.Untuk mengetahui 
bagaimana pelayanan terbaik yang seharusnya dilakukan oleh fiskus kepada wajib pajak, diperlukan juga pemahaman mengenai hak dan kewajiban sebagai Fiskus. Kewajiban fiskus yang diatur dalam undangundang perpajakan adalah:1) Kewajiban untuk membina wajib pajak; 2) Kewajiban merahasiakan data wajib pajak; 3) Kewajiban melaksanakan putusan.

Sementara itu terdapat pula hak-hak fiskus yang diatur dalam undang-undang perpajakan antara lain:1) Hak menerbitkan NPWP dan NPPKP secara jabatan; 2) Hak menerbitkan surat ketetapan pajak; 3) Hak menerbitkan surat paksa dan surat perintah melaksankan penyitaan; 4) Hak melakukan pemeriksaan dan penyegelan; 5) Hak melakukan atau mengurangi sanksi administratif

Hak melakukan penyidikan, pencegahan dan penyanderaan Apabila petugas pajak melakukan kesalahan berkaitan dengan pelaksanaan ketentuan perpajakan, bertindak diluar kewenangannya, menyalahgunakan kekuasaan dengan maksud menguntungkan diri sendiri, dalam hal demikian wajib pajak dapat mengadukan pelanggaran yang dilakukan pegawai pajak (fiskus) tersebut kepada unit sub pelayanan dan Humas Ditjen Pajak Departemen Keuangan.

Upaya peningkatan kualitas pelayanan meliputi segala jenis pelayanan yang berhubungan dengan proses pemenuhan kewajiban maupun hak wajib pajak dibidang perpajakan misalnya kebersihan ruangan dan pendingin ruangan (AC) yang dapat memberikan kenyamanan bagi wajib pajak, kelengkapan peralatan dan perlengkapan ruangan lainnya seperti pengeras suara dan papan petunjuk ruangan yang memudahkan wajib pajak dalam memenuhi kewajiban perpajakannya, kemudahan tata cara pembayaran, kecakapan petugas pajak dalam melayani hingga penampilan petugas pajak.

Pengertian kepatuhan pajak (tax compliance) adalah bahwa wajib pajak mempunyai kesediaan untuk mematuhi kewajiban pajaknya sesuai aturan yang berlaku tanpa perlu diadakannya pemeriksaan, investigasi seksama (obtrusiveinvestigation), peringatan atau pun ancaman dan penerapan sanksi baik hukum maupun administrasi (Loebbecke, 2003). James dan Alley, (2004) mengemukakan kepatuhan wajib pajak sebagai suatu tingkatan dimana seorang wajib pajak memenuhi peraturan perpajakan di negaranya. Pendapat lain tentang kepatuhan wajib pajak juga dikemukakan oleh Kiryanto (2000), seperti dikutip oleh Jatmiko (2006) yang menyatakan suatu iklim kepatuhan wajib pajak adalah: wajib pajak paham dan berusaha memahami UU Perpajakan, mengisi formulir pajak dengan benar, menghitung pajak dengan jumlah yang benar, membayar pajak tepat pada waktunya

Internal Revenue Service (Brown dan Maznur, 2003) megelompokkan kepatuhan waajib pajak terdiri dari 3 tipe kepatuhan: (1) Kepatuhan penyerahan SPT (filling compliance), (2) kepatuhan pembayaran (Payment complianc),(3) Kepatuhan pelaporan (reporting compliance). Ketiga tipe kepatuhan tersebut dapat diukur secara bersama-sama akan memberikan gambaran yang komperhensif tentang kepatuhan wajib pajak. Namun demikian kepatuhan perpajakan juga menuntut keikut sertaan aktif wajib pajak dalam menyelenggarakan perpajakannya sebab Sebagian besar pekerjaan dalam pemenuhan kewajiban perpajakan itu dilakukan sendiri oleh wajib pajak atau dengan bantuan praktisi perpajakan profesional. Beberapa peneliti kepatuhan pajak menggunakan konsep Theory of planned Behavior (ajzen, 1991) untuk menjelaskan prilaku kepatuhan pajak 
wajib pajak. Berdasarkan teori ini, prilaku individu untuk tidak atau patuh terhadap ketentuan perpajakan di pengaruhi oleh niat berperilaku dan niat berperilaku tidak atau patuh di pengaruhi oleh tiga factor yaitu: 1) behavioral belief yaitu keyakinan akan hasil dari suatu perilaku (outcome belief) yang membentuk variabel sikap (attitude), 2) normative belief yaitu keyakinan individu terhadap harapan normatif yang menjadi rujukannya yang membentuk variabel normative subjektif (subjective norm), dan 3) Control belief yaitu keyakinan/persepsi individu tentang keberadaan hal-hal yang mempengaruhi (menghambat atau mendukung) perilaku yang membentuk variabel kontrol perilaku yang dipersepsikan (perceived behavior alcontrol).

Penyebab wajib pajak tidak patuh bervariasi, sebab utama adalah penghasilan yang diperoleh wajib pajak yang utama ditujukan untuk memenuhi kebutuhan hidupnya.Timbulnya konflik antara, kepentingan diri sendiri dan kepentingan negara.Sebab lain adalah wajib pajak kurang sadar tentang kewajiban bernegara, tidak patuh pada aturan, kurang menghargai hukum, tingginya tarif pajak, dan kondisi lingkungan sekitar (Jatmiko, 2006).

Umumnya masyarakat disetiap negara memiliki kecendrungan untuk meloloskan diri dari pembayaran pajak.Permasalahan tersebut timbul dari pemikiran bahwa membayar pajak adalah pengorbanan yang dilakukan warga negara dengan menyerahkan sebagian hartanya kepada negara dengan sukarela.Usaha yang dilakukan wajib pajak untuk meloloskan diri dari pajak merupakan usaha yang disebut perlawanan terhadap pajak.Berbagai bentuk perlawanan sebagai bentuk reaksi ketidak cocokan ataupun ketidak puasan terhadap diberlakukannya pajak sering kali diwujudkan dalam bentuk perlawanan pasif dan perlawanan aktif. Pendekatan yang lazim digunakan untuk menganalisis kepatuhan pajak yaitu:

Menurut pendekatan ekonomi kepatuhan perpajakan merupakan manifestasi prilaku manusia rasional yang membuat keputusan berdasarkan evaluasi antara manfaat dan biaya.Faktor yang menentukan kepatuhan dalam pendekatan ini adalah tingkat tarif, Struktur Sanksi, dan kemungkinan terdeteksi oleh hokum; Pendekatan Psikologis menyatakan perilaku kepatuhan pajak di pengaruhi oleh faktorfaktor dan cara pandang seseorang mengenai moralitas penyeludupan pajak yang berkaitan dengan ide dan nilai- nilai yang dimilikinya, persepsi dan sikap terhadap probabilitas kemungkinan terdeteksi, kerangka subjektif atas keputusan pajak; Pendekatan Sosiologis: melihat sebab-sebab penyimpangan prilaku seseorang melalui kerangka sistem sosialnya. Dorongan/tekanan masyarakat akan membentuk prilaku yang sama efektifnya dengan sistem reward and punishment yang dibuat oleh pemerintah. Menurut pendekatan ini faktor yang mempengaruhi tax avoidance dan tax evasian adalah sikap terhadap pemerintah, pandangan mengenai penegakan hukum oleh pemerintah, pandangan mengenai keadilan dan sistem perpajakan, kontak dengan kantor pajak dan karakteristik demografi.

Berdasarkan penelitian sebelumnya didapatkan hasil bahwa penerapan e-filling berpengaruh positif pada kepatuhan wajib pajak orang pribadi yang terdaftar di KPP Pratama Denpasar Timur. Penerapan $e$ filling ini sangat membantu mempermudah dalam membayar pajak bagi wajib pajaknya, semakin baik penerapan e-filling yang diberikan oleh petugas pajak, maka kepatuhan wajib pajak juga akan meningkat. Kualitas pelayanan berpengaruh positif pada kepatuhan wajib pajak orang pribadi yang terdaftar di KPP 
Pratama Denpasar Timur. Kuliatas pelayanan dapat berikan kepada wajib pajak berupa pelayanan yang baik dari petugas pajak serta fasilitas yang memadai dapat meningkatkan kapatuhan wajib pajak mengenai kewajiban perpajakannya. Semakin baik kualitas pelayanan yang diberikan, kepatuhan wajib pajak dalam melaksanakan kewajiban perpajakannya akan semakin baik. (Mahendra \& Budiartha, 2020).

Selanjutnya penelitian oleh (Safitri \& Silalahi, 2020) menemukan bahwa kualitas pelayanan fiskus dan pemahaman peraturan perpajakan secara parsial tidak mempengaruhi kepatuhan wajib pajak, namun penerapan sistem e-filling memiliki pengaruh positif pada kepatuhan wajib pajak.

Dengan demikian berdasarkan uraian diatas peneliti tertarik untuk meneliti tentang Implementasi E-Filling Dan Kualitas Pelayanan Pada Kepatuhan Wajib Pajak Orang Pribadi Di Kantor Pelayanan Pajak (KPP) Bandar Lampung.

\section{METODE PENELITIAN}

Populasi yang diambil yaitu jumlah wajib pajak orang pribadi di Bandar Lampung yaitu berjumlah 900. Metode yang digunakan untuk pengambilan sampel adalah Teknik pengambilan sampel yang digunakan adalah teknik Stratified Random Sampling yaitu pengambilan sampel dari populasi dengan membagi kelompokkelompok dalam kelompok tersebut diambil secara sengaja,jumlah sampel 400 responden.

Teknik pengumpulan data dengan cara melakukan survey yaitu pengambilan data secara langsung maupun tidak langsung terhadap objek penelitian mengenai masalah yang di teliti. Melihat situasi dan kondisi kepatuhan wajib pajak orang pribadi dan wawancara dengan informasi mengenai efilling, kualitas pelayanan dan sanksi pajak yang ada di KPP Bandar Lampung sehingga bisa mendapatkan data primer melalui kuesioner. Kuesioner adalah pengumpulan data yang dilakukan melalui pengisian kuesioner secara langsung terhadap responden yang telah ditentukan sebagai sampel penelitian, sedangkan metode kualitatif digunakan interprestasi adari data kuantitatif..

Uji instrument data dengan uji validitas dilakukan untuk menguji butir pertanyaan yang disebarkan pada sampel yang bukan responden sebenarnya (muhidin, 2007). Validitas adalah suatu ukuran yang menunjukkan tingkat - tingkat kevalidan atau ketepatan suatu instrument (sugiyono, 2005), Uji reliabilitas untuk mengukur sejauh mana alat ukur yang digunakan dapat dipercaya artinya bila alat ukur tersebut diujikan berkali-kali hasilnya tetap. Menurut nunaly dalam widhiarso (2009) standar reliabilitas yang dapat diterima adalah jika alpha $\geq 0,6$, uji normalitas digunakan untuk mengetahui apakah data yang diperoleh berdistribusi normal atau sebaliknya. Alat ini menggunakan kolmogorov smirnov. Hal ini bertujuan untuk memperkecil tingkat kesalahan baku dan mengetahui apakah data yang akan digunakan dalam model berdistribusi normal atau tidak. Analisi jalur merupakan sebuah analisis yang menentukan besarnya hubungan kausal antar variabel baik pengaruh secara langsung maupun tidak langsung (sewall wright dalam ety rochaety, 2009). Analisis jalur yang dipakai dalam penelitian ini adalah dua persamaan yaitu $X$ sebagai variabel eksdogen sedangkan variabel $\mathrm{Y}$ dan $\mathrm{Z}$ sebagai variabel endogen.

\section{HASIL DAN PEMBAHASAN}

Hasil olah data untuk jalur satu (1) dapat dilihat dari perhitungan model 
summary dan perhitungan coeffisien di bawah ini:

Tabel 1. Tabel Model Summary

Model Summary

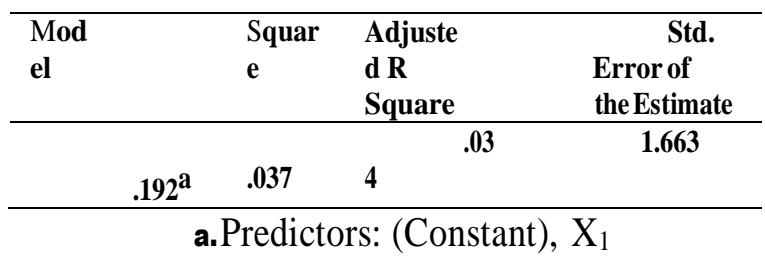

Tabel 2. Tabel Coefficients
Hasil olah data untuk jalur dua (2) adalah sebagai berikut:

Tabel 3. Tabel Summary

Model Summary

\begin{tabular}{|c|c|c|c|c|}
\hline Mode & $\mathbf{R}$ & $\mathbf{R}$ & A & Std. \\
\hline 1 & uare & $\begin{array}{l}\text { Isted } \\
\text { |uare }\end{array}$ & $\begin{array}{r}\text { R ror of } \\
\text { timate }\end{array}$ & the \\
\hline 1 & & & & 2.515 \\
\hline $16^{\mathrm{a}}$ & 1 & 9 & & \\
\hline
\end{tabular}

a. Predictors: (Constant), X1

Tabel 4. Tabel Coefficients

\begin{tabular}{|c|c|c|c|c|c|}
\hline & & Coe & cients $^{\mathrm{a}}$ & & \\
\hline \multirow[t]{2}{*}{ Model } & \multicolumn{2}{|c|}{$\begin{array}{l}\text { Unstandardiz } \\
\text { ed } \\
\text { Coefficients }\end{array}$} & \multirow{2}{*}{$\begin{array}{l}\text { Standard } \\
\text { ized } \\
\text { Coefficie } \\
\text { nts } \\
\text { Bet } \\
\text { a }\end{array}$} & \multirow[t]{2}{*}{$T$} & \\
\hline & B & $\begin{array}{l}\text { Std. } \\
\text { Error }\end{array}$ & & & \\
\hline $\begin{array}{ll} & \text { (Const } \\
\text { ant) }\end{array}$ & $\begin{array}{r}15.04 \\
9\end{array}$ & .283 & & $\begin{array}{r}53.1 \\
34\end{array}$ & $\begin{array}{r}.0 \\
00\end{array}$ \\
\hline $\mathrm{X} 1$ & .054 & .014 & .192 & $\begin{array}{r}3.89 \\
3\end{array}$ & $\begin{array}{r}.0 \\
00\end{array}$ \\
\hline
\end{tabular}

a. Dependent Variable: $\mathrm{X}$

Berdasarkan output model jalur I pada bagian tabel coefficients dapat diketahui bahwa nilai signifikansi dari variabel implementasi e-filling (X1) yaitu 0,000 lebih kecil dari 0,05. Hasil ini memberikan kesimpulan bahwa model jalur I, yakni variabel implementasi e-filling (X1) berpengaruh signifikan terhadap kualitas pelayanan (X2). Besarnya nilai $\mathrm{R}$ Square yang terdapat pada tabel model summary adalah sebesar 0,037, hal ini menunjukkan bahwa kontribusi atau sumbangan pengaruh variabel implementasi e-filling (X1) terhadap kualitas pelayanan (X2) adalah sebesar $3,7 \%$ sementara sisanya $96,3 \%$ merupakan kontribusi dari variabel lain yang tidak dimasukkan dalam penelitian.
Berdasarkan output model jalur II pada bagian tabel coefficients dapat diketahui bahwa nilai signifikansi dari variabel implementasi e-filling (X1) yaitu 0,035 lebih kecil dari 0,05. Hasil ini memberikan kesimpulan bahwa model jalur II, yakni variabel implementasi e-filling (X1) berpengaruh signifikan terhadap kepatuhan wajib pajak orang pribadi (Y2). Besarnya nilai $\mathrm{R}$ Square yang terdapat pada tabel model summary adalah sebesar 0,011 , hal ini menunjukkan bahwa kontribusi atau sumbangan pengaruh variabel implementasi e-filling (X1) terhadap kepatuhan wajib pajak orang pribadi (Y2) adalah sebesar $1,1 \%$ sementara sisanya $98,9 \%$ merupakan kontribusi dari variabel lain yang tidak dimasukkan dalam penelitian.Sementara 
itu,untuk nilai e1 dapat dicari dengan rumus $\mathrm{e} 1=\sqrt{ }(1-0,011)=0,994$.

Uji hipotesis pada penelitian ini adalah sebagai berikut: analisis pengaruh $\mathrm{X} 1$ terhadap X2 dari analisis di atas diperoleh nilai signifikansi X1 sebesar 0,000 $<0,05$, sehingga dapat disimpulkan bahwa variabel implementasi e-filling (X1) berpengaruh terhadap kualitas pelayanan (X2), analisis pengaruh $\mathrm{X} 1$ terhadap $\mathrm{Y} 2$ dari analisis di atas diperoleh nilai signifikansi sebesar $0,035<0,05$ sehingga dapat disimpulkan bahwa variabel implementasi e-filling (X1) berpengaruh terhadap kepatuhan wajib pajak orang pribadi (Y2).

\section{KESIMPULAN}

Berdasarkan hasil dan pembahasan tentang : Implementasi E-Filling Dan Kualitas Pelayanan Pada Kepatuhan Wajib Pajak Orang Pribadi Di Kantor Pelayanan Pajak (KPP) Bandar Lampung

1. Analisis pengaruh $X 1$ terhadap $X 2$ dari analisis di atas diperoleh nilai signifikansi $\mathrm{X} 1$ sebesar $0,000<0,05$, sehingga dapat disimpulkan bahwa variabel implementasi e-filling (X1) berpengaruh terhadap kualitas pelayanan (X2).

2. Analisis pengaruh $\mathrm{X} 1$ terhadap $\mathrm{Y} 2$ dari analisis di atas diperoleh nilai signifikansi sebesar 0,035 <0,05 sehingga dapat disimpulkan bahwa variabel implementasi e-filling (X1) berpengaruh terhadap kepatuhan wajib pajak orang pribadi (Y2).

Dengan demikian bahwa implementasi $e$ filling dan kualitas pelayanan berpengaruh terhadap kepatuhan wajib pajak orang pribadi di kantor Pelayanan Pajak Bandar Lampung.

DAFTAR PUSTAKA
Astari, D. I. (2011). Pengaruh Tingkat Kepuasan Pelayanan, Pemahaman Perpajakan, Keadilan Perpajakan dan Kesadaran Perpajakan Terhadap Tingkat Kepatuhan Wajib Pajak Orang Pribadi Di KPP Tg.Pinang Kepulauan Riau".

Damayanti, T. (2004). Pelaksanaan Self Assesment System Menurut Wajib Pajak (Studi Kasus pada Wajib Pajak Badan Salatiga). Jurnal Ekonomi Dan Bisnis, Volume X No. 1, 10928.

Haryadi, H. (2009). Administrasi Perkantoran untuk Manajemen \& Staf. Transemedia Pustaka.

Ihsan, M. (2013). Pengaruh Pengetahuan Wajib Pajak, Penyuluhan Pajak, Kualitas Pelayanan Pajak, dan Pemeriksaan Pajak Terhadap Kepatuhan Wajib Pajak Badan di Kota Padang. Fakultas Ekonomi: Universitas Negeri Padang.

Jatmiko, Nugroho Agus. (2006), Pengaruh Sikap Wajib Pajak Pada Pelaksanaan Sanksi Denda, Pelayanan Fiskus dan Kesadaran Perpajakan Terhadap Kepatuhan Wajib Pajak (Studi Empiris Terhadap Wajib Pajak Orang Pribadi di Semarang). Tesis Program S2 Magister Akuntansi Universitas Diponegoro. Tidak Dipublikasikan.

Lai, et. al. (2012). Configuring Quality Management And Marketing Implementation And The Performance Implications For Industrial Marketers. Jurnal Industrial Marketing Management, 41.

Mahendra, I. P. A. J., \& Budiartha, I. K. (2020). Pengaruh Penerapan EFilling Perpajakan, Kualitas 
Pelayanan, Kesadaran Wajib Pajak, dan Sanksi Perpajakan pada Kepatuhan WPOP. E-Jurnal Akuntansi, 30(5), 1183. https://doi.org/10.24843/EJA.2020.v 30.i05.p09

Muliari, N.K., Setiawan P.E., (2010). Pengaruh Persepsi tentang Sanksi Perpajakan dan Kesadaran Wajib Pajak pada Kepatuhan Pelaporan Wajib Pajak Orang Pribadi di Kantor Pelayanan Pajak Pratama Denpasar Timur.

Safitri, D., \& Silalahi, S. P. (2020). Pengaruh Kualitas Pelayanan Fiskus, Pemahaman Peraturan Perpajakan Dan Penerapan Sistem E-Filling Terhadap Kepatuhan Wajib Pajak: Sosialisasi Perpajakan Sebagai Pemoderasi. Jurnal Akuntansi dan Pajak, 20(2). https://doi.org/10.29040/jap.v20i2.6 88

Siti Kurnia Rahayu. (2010) Perpajakan Indonesia. Konsep dan Aspek Formal, Graha Ilmu, Yogyakarta. Sugiarto dan Wahyono 2005

Supadmi, (2010) Meningkatkan Kepatuhan Wajib Pajak Melalui Kualitas, Jurnal Akuntansi dan Bisnis: Fakultas Ekonomi Universitas Udayana

Tatiana, V. R. dan P. H. (2009). Dampak Program Sunset Policy Terhadap Faktor-Faktor Yang Mempengaruhi Kemauan Untuk Membayar Pajak. Proceeding Simposium Nasional XI. Pontianak. 